\title{
地域計画における工学的モデル論
}

\author{
五十嵐日出夫*
}

\section{1. 地域科学と地域計画}

科学に拈いては「発見」と「認識」が尊ばれ，技術に颃いては「発明」と「創造」が重んじ られる。もちろん技術に颃いても，その革新は新しい事物の発見や事象の正しい認識に基礎を 置くことから，「発見」と「認識」も尊ばれはするが，その理由はあくまでも「発明」や「創造」 の基礎になるからにしかすぎず，実用の技術につながらないならば，知識の範囲にとどまって 有用な情報とはなり得ない。

一般に科学は, 個々の特殊な経験を抽象化して一般理論を作り上げる。それに対して技術(技 術学=工学) は, その一般理論を基礎にして今直面している問題に適用し, 解決に導かれるよ らな個別理論を作り上げ，それによって具体的問題を処理しょうとする。ここに科学的モデル と工学的モデルの大きな相違がある。

地域科学のモデルと地域計画のモデルとの関係もこれと同様である。地域科学の一般的モデ ルを基礎にしながら, 計画対象地域の地域性を加味して工学的モデル（係数やパラメータを替 えたり, 組合せを変えたりした問題解決型の個別的モデル）を作り上げ，実際の地域計画に利 用する。それら二つのモデルの性格は，どちらかとい学ば前者は分析的で現象記述に力点が置 かれ，後者は総合的で問題解決に力点が置かれる。

\section{2. 科学的モデル}

我々は，自然現象あるいは社会現象を科学の対象とするために，そのままでは把握し難いの で，ある側面に注目して，見たこと感じたことを抽象化し，直感と推理によってモデルをつく る。モデルによって把握し，説明しょうとするわけである。この意味でのモデルには 2 種類あ る。すなわち，対象モデルとモデル理論である。一概にはいえないが，自然科学でモデルとい らのは対象モデルであり，モデル理論とは，対象モデルについての理論である。

(1) 対象モデル

対象モデルを分類すれば, 次の 4 種類になる。(1) 単純化モデル (近似モデル-I), (2) 構成モ

* 北海道大学 
デル（近似モデル-II)，(3) 同型モデル，(4) 相似モデルである。また（3)の同型モデルは，(i) 類比モデルと，(ii）表現モデルとに分けられる。

(1) の単純化モデルは, 対象を理想化あるいは単純化したモデルである。理想気体, 単振動, 完 全流体などはこの種類のモデルである。このモデルは，実際の対象が一応わかっているが, その ままでは複雑で取り扱光ないときに用いられる。したがって実在に対して一つの近似であるこ とから，近似モデルの一種であるともいえる。

(2)の構成モデルは，実際の対象が大きすぎたり小さすぎたりして見えず，もともとよくわか らないとき，我々はその対象が「かくあるだろら」と想像してモデルをつくる。これが構成モ デルである。太陽系のモデル，原子模型などはこれに相当する。

(3)の同型モデルには，（i）類比モデルと，(ii）表現モデルとがある。我々は実際の対象が 分り難いとき，それと同じょうな振舞をすると考学られるもっとも分り易いもので説明しょう とする。このときその分り易いものの方を, 分り難いものの同型モデルという。水流は電流と ある範囲で同じょうな挙動をするので, 電流を説明するために水流が用いられることがある。こ のとき水流は電流の同型モデルである。ぬた交通流に対して電流が用いられるならば，電流は 交通流の同型モデルである。電流は交通流の近似ではなく，単なる類比あるいは代用であるか ら，このモデルは類比モデルあるいは代用モデルともいわれる。

自然現象を数学的に表現するとき,その表現はその自然現象とある範囲で同型になっている。 しかしそれは，交流を正弦関数で形式的に表現する場合のように，実質的な類比ではない。そ れゆえに, このモデルは数学的な意味での同型モデルではあるが類比モデルではなく, 表現モ デルである。科学では演繹を尊重することから，この表現モデルが最も重要になる。

(4)の相似モデルは, プラモデルとか地図, 設計図, 写真などである。実物も一種の相似モデ ルである。相似は合同を含むからである。

(2) モデル理論

対象モデルの理論もモデルといわれることがある。そして，この意味でのモデルは多くの場 合単純化モデルである。例壳ば経済学では, 実際の人間の単純化モデルとして経済人 (homo economicus）を仮定し，この経済人の行動理論をモデルという。前述のように，単純化モデ

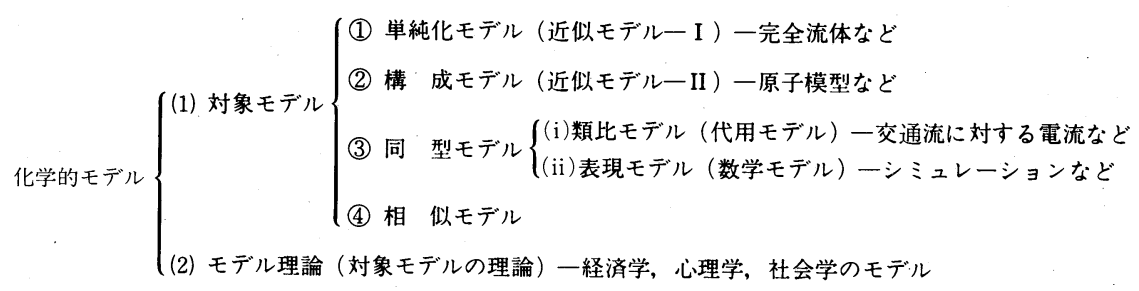

図 1 科学モデルの分類 
ルは近似モデルであるから，それについての理論は近似モデルである。

以上の科学モデルの関係を図示すれば図 1 のよらである。

\section{3. 環境の見方によるモデルの分類}

\section{1 モデルの分類}

我々の環境を見る見方には，(1) 必然論的見方，(2) 蓋然論的見方，(3) 規範論的見方，(4) 偶 然論的見方とがある。

(1) の必然論的見方とは,「Aであれば，必ずBである」という見方であって，因果論的な見方， 決定論的な見方ともいわれる。同一のブロックに当った一定の波は常に同一の形で砕けるよう に，同じょうな（自然）環境は，そこにある（自然）社会の動きに対して常に同じょうな道を 指定するという見方である。

(2) の蓋然論的見方とは，「Aであれば，Bである可能性がある」という見方であって，確率論 的見方，可能論的見方ともいわれている。社会が，それぞれの環境に対して技術をもって働き かけ，それに適応していく過程は，必ずしも決定論的な因果関係に支配されてはいない。むし ろ社会は, 環境がもっている可能性の中から自己の生存と発展に必要なものを能動的に選択し, 取り入れて新しい文化を形成し，その文化を媒介として環境との関係を保っている。

(3) の規範論的見方とは,「Aの問題を解くにはBを規範にすれば, 実践的な意味で問題が解決 できる可能性がある」という見方である。もちろんこの可能性は，(2)が予想されるからにもよ る。ただ蓋然的見方に拉ける可能性は，強くはないが因果関係によって機械論的に保証されて いるのに対して，規範論的見方における可能性は，その時，その場所における社会（文化）的 関係によって目的論的に保証されているにしかすぎない。

(4)の偶然論的見方とは，「Aであっても，Bであるといら可能性がないかもしれないし，ない ともいえない。全く分らない」という見方である。一度波が当ればブロックに着いていた昆布 や海苔がちぎれたり，とれたりしてブロックが変形する。ブロックが変形しないまでも，ブロッ クの動くことが予想される。また，同一の波といっても実際にはまずありえないから，波の砕 ける形が同一であることは実際にはあり得ない。もし同一であったとしても，それは全くの偶 然にしかすぎないとする見方である。

以上のことを念頭に置きながら，我々の環境の見方に基づいてモデルを分類し位置づけてみ ると, 図2のよらになる。

なお，因果論的モデルに物理学を，確率論的モデルに経済学を，規範論的モデルに法学をそ れぞれ対応させたのは，全くの便宜的な意味にしかすぎない。 


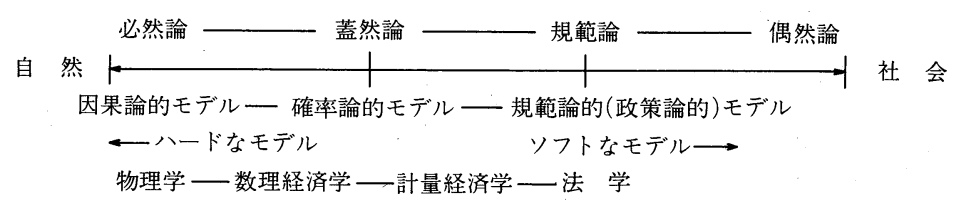

図 2 環境の見方によるモデルの位置付け

\section{2 規範論的モデルの実例 ——地方バス路線評価モデル—}

規範論的モデルは認識と利害の密接不可分な一体と考兄られるコミュニティ (community) の志向性に裏付けられた社会的規範の形をとる。換言すれば，規範論的モデルはそのコミュニ ティの実践的合理性を表現しているモデルとも言いうるであろう。

この実践的合理性は,コミニュケーション(communication)を通じてはじめて得られる。た だしここに拈けるコミュニケーションは二つの内容をもっている。一つは次の実例に挙げる バス利用実態調査におけるような比較的主観の入らない情報交換であり，他はモデルの妥当性 が内容となるような倫理的意味をもつ情報交換である。すなわち規範論的モデルはコミュニ ティの行動実態に裏付けられた妥当性によって支持されているモデルである。

換言すれば, 規範論的モデルは法手続のそれに似て, 規範論的モデルに準拠した行動をとれば, その行動はコミュニティからの容認が期待されらる。従ってコミュニティを構成する人々の行 動は，この規範論的モデルによって説明が可能であり，かつ予想されうるのである。このよう に規範論的モデルは人々の行動を論理的側面と倫理的側面の両面から描写するモデルである。

さて次に，この規範論的モデルの実例として地方バス路線評価モデルを挙げる。このモデル は北海道北東部の過疎バス路線（紋別郡滝上町本流線, 白糠郡音別町茶安別線, 十勝郡浦幌町 留真温泉線）の改廃について評価しょうとしたものであり, 図 3 のように二段階構成となって いる。

すなわち，第一段階は過疎バス路線の公共性を判断するためのものであり，地域社会を維持す る上で公共交通機関に課せられた最小限の責任を評価するものである。従って，この段階で \{Yes\} の評価が下されると, 第二段階の評価を受けることなくそのバス路線は〔維持〕すべき ものとした。すなわち第一段階では $\mathrm{Q}_{1} \sim \mathrm{Q}_{3}$ の評価項目によってバス路線の公共性を評価する。

$\left[Q_{1}\right]$ ：公費負担されている小・中学生の通学手段の確保

$\left[Q_{2}\right]$ ：自家用車非保有所帯に技ける最小限の通院交通の確保

$\left[Q_{3}\right]$ : 自家用車非保有所帯に和ける最小限の買物交通の確保

$\mathrm{Q}_{1}$ は小・中学生の通学交通の確保を意図したものであり, 評価対象バス路線に公費負担の 小・中学生が乗車していたならば，そのバス路線は無条件に維持すべきものとした。なぜなら 


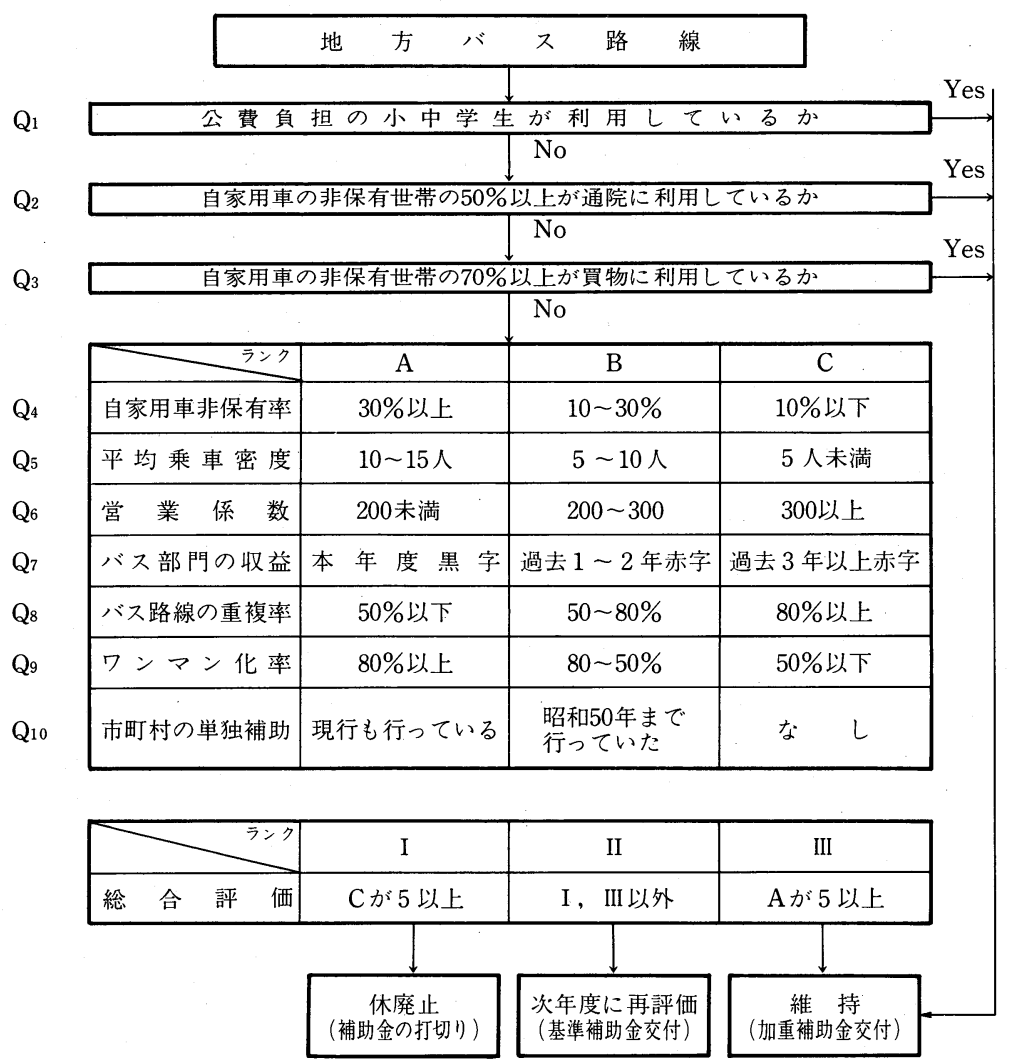

図 3 地方バス路線評価モデル（規範論的モデルの例）

ば，乗合バスがスクール・バス化していることにそもそもの原因があるとしても，このような バス路線を廃止したならば，児童・生徒たちから義務教育を受ける権利を奪ってしまうことに なるからである。

自家用車非保有所帯に怙ける通院・買物交通の確保も地域社会を維持する上で大切な条件と なる。しかしながら, 通院, 買物交通については通学交通の場合とは異なり, 一定の足切り基 準を設けた。

第二段階は第一段階に括いて〔維持〕という評価に至らなかったバス路線に対して，採算性 の面から評価しょうとするものである。

つまり第二段階では $Q_{4} \sim Q_{10}$ までの 7 評価項目があり，バス路線はそれぞれの評価項目におい て, A〔維持〕, B〔保留〕， C〔休廃止〕の評価が下される。各評価項目に拉けるランク付け （特にCランク）は，次のようにして決めたものである。

$\left[Q_{4}\right]$ : 自家用車の非保有率は Transportation poor

所帯の状況を示すものであり，自家用車の非保有率が低ければ，逆に言学ば自家用車の保有 
率が高ければ, バス路線の休廃止の影響はさほど深刻なものにはならないであろら。従って, バ ス路線の沿線所帯のうち自家用車を保有していない所帯が $10 \%$ 以下の場合には, そのバス路線 を休廃止することにした。な扣従来の研究では自家用車の保有率をもってバス路線の評価を 行っているが，この指標では自家用車の非保有所帯の実態を把握できないことに問題が残され ている。

$\left[Q_{5}\right]$ : 市町村の単独補助の有無は, 市町村がそのバス路線の維持に関してどれだけの熱意を もっているかを示す尺度と考兄られるので市町村の単独補助が過去に括いても一切なされてい ないバス路線は休廃止することにした。

$\left[\mathrm{Q}_{6}\right]$ : 平均乗車密度はバス路線の利用効率を示す指標であり, この数值の低い路線注ど輸送 効率が悪いことを示している。第 3 種生活路線の基準である平均乗車密度が 5 人未満のバス路 線は休廃止することにした。

$\left[Q_{7}\right]$ : 営業係数は 100 円の収入を得るために, どれだけの経費がかかったかを示す指標であ る。営業係数が 200 以上のバス路線は, 企業の内部補助あるいは運賃改訂があったとしても, 今 後の人件費等の増加を考学ると, 維持していくのが非常に難しいとされている。それゆえ, 営 業係数が 300 以上のバス路線は休廃止することにした。

$\left[Q_{8}\right]$ : 企業のバス部門の収益は, 他のバス路線の収益によって評価対象となっているバス路 線を維持できるか否かを判定するものである。バス部門の収益が過去 3 年以上赤字であれば, 企 業の内部補助は今後とも期待することができないので, このバス路線は休廃止することにした。

$\left[\mathrm{Q}_{9}\right]$ : バス路線の重複率は, 同一の道路に他の路線がどれだけ重複しているかを示す指標で ある。バス路線の重複率が高ければ，一方のバス路線を休廃止してもさほど大きな影響は考兄 られない。それゆえにここでは $80 \%$ 以上の重複率を有するバス路線は休廃止することにした。

$\left[\mathrm{Q}_{10}\right]$ : ワンマン化率は, バス企業の経営努力を示す指標として広く用いられているものであ る。北海道における昭和 50 年度の平均ワンマン化率は $67 \%$ であったので，これより低い $50 \%$ 以下のワンマン化率を示すバス会社の路線は休廃止することにした。

ところで, 過疎バス路線の最終的な休廃止の決定は, 第二段階の評価ステップに扎いてC評 価が 5 項目以上あるバス路線を対象とした。なぜならば，この種のバス路線は地域社会に打い て公共財としての機能がすでに失われ，しかも採算性や輸送効率が非常に悪いバス路線とみな し得るからである。逆に, 維持すべきバス路線は, 第一段階に掞いて 1 項目でも $\{\mathrm{Yes}\}$ の評価 が下されたものか，第二段階に执いて A 評価が 5 項目以上あるバス路線とした。それは第二段 階に揖いても $\mathrm{Q}_{4}, \mathrm{Q}_{5}$ のようにバス交通の公共性に関する評価項目を設けているので，A評価が 5 項目以上あるバス路線は, 過疎バス路線としては輸送効率が高く, しかも公共性の高い路線と 評価できるからである。これ以外のバス路線は結論を保留し, 次年度にさらに再評価を行うも 
のとした。なお， $\mathrm{Q}_{2} \sim \mathrm{Q}_{10}$ までに用いた基準值はあくまでもこの事例のために定められたもので あり, いつでも，どこでもこれらの基準值によればよいというような時空を超越した普遍的数 值ではない。その時期と場所により，その沿線地区の利用実態調査に基づいて定められるもの で，休廃止あるいは維持に対する大方の合意が得られるように定められるべきものである。

ただこのフローモデルが示す手続は，法令などと同様に，一応一般的なものと考学られるの で, 規範論的モデルと称されるものである[1]。

\section{4. 行動モデルと意識モデル}

\section{1 行動モデルと意識モデル}

ここに拈ける行動モデル (behavior model) とは, 調査対象者のあらわな行動 (overt behavior) を外部から客観的に観察することによって得られたデータに基づき構築されたモデルをい い, 意識モデル (attitudinal model) とは, 調査対象者のあらわな行動, あるいはあらわでない行 動（covert behavior）を調査対象者の意識的報告を通じて知り得たデータに基づき構築された モデルをいう。従って，景観工学等における評価モデルの大部分は，意識的報告としての言語 的手段によって得られたデータに基づき，構築されたモデルであるから，意識モデルである。

そもそも計画とは, 将来の目的の達成を目指して予測の成果を踏まえながら, 現在, 我々は 何をなすべきかを決定することである。それゆえに地域計画のモデルは，現実には実現してい ない将来の状況に㧤いてこそ有効でなければならない。しかるに行動モデルは，現在実現して いる情況に和いて生起した行動の観察あるいは調査によって得られたデータに基づいて現在の 情況に相似させて構築されたモデルであるから, 常に次のような疑問がつきまとう。(1) 行動モ デルは，現在の物理的環境及び心理学的環境に拈いて生起した行動に基づいて構築されたもの であるから，将来に拉いてこれらの環境が大幅に変化したとき，果してこの行動モデルの適用 が有効であるか否かの疑問。(2) 行動モデルを用いた要因分析では, 分析に耐えらるデーターの 収集に莫大な費用と労力を要する。たと兄ば，新交通システムの導入計画に括ける既存の交通 システムと新交通機関別分坦モデルの構築について考えてみよう。要因として交通目的, 運賃,

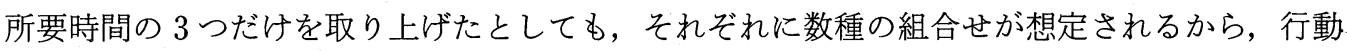
モデルの構築には膨大なデータが必要となり,ある場合は採取不可能なことにもなる。(3) 地域 計画に用いられるデータのらち，アンケート調査によって採取されたデータは，物理実験など で得られたデータのように客観的なものではない。すなわち，回答は既に調査対象者の意識の フィルターを通して言語的に報告されたものであり，広義には意識調査に基づくデータである ともいえる。

一方, 意識モデルに和いては次のような疑問がある。(1) 数学モデルを構築するには, 意識を 
何らかの手法を用いて数量化しなければならない。(2)トレード・オフの関係にある複数の要因 (たと兊ば料金と所要時間)でモデルを構築する場合には，これらの要因の総合評価法を確立し て扔かなければならない。(3) 頻繁に用いられる重回帰モデルや数量化理論モデルでは, 理論の 前堤として要因間の独立性が仮定されているが，このことがモデルの適用を制約している。(4) 行動モデルの構築に拈けるように, 意識モデルの構築に掞いても多種類の誤差が生じる。しか し誤差そのものの分析や吟味はまだほとんどなされていない,などである。しかし最もよく指 摘される疑問点は, 人間の意識は絶觉ず流動しているものであり，停まっていないものである し, 生活環境によっても異なってくる。従ってそのような不安定で不確実なデータを基にして 構築されたモデル，すなわち意識モデルは，時間の経過に対して耐久性 (durability)がないば かりでなく，空間的にも適用性がないのではないかという疑問である。しかし人間の行動は，い わゆる意識主義的方法論のみによっても理解され得ないように, 行動主義的方法論のみによっ ても理解できない場合が多い。特に，地域計画が達成されるのは遠い将来のことであるし，そ こに住んでいる人々も移り変り, 計画の達成によって環境も明らかに変ってしまう。物理学の ように時空的，社会的空間の均等性が保障されていないのである。従って経験の外にある将来 に起こるであろう事象を考える場合には，過去の行動データに頼るばかりでなく，積極的に意 識データにも頼らざるをえないことにもなる。むしろ意識データによってモデルを構成し，行 動データによって検証するといらようなモデル構成法が認められなければならない。これに よって地域計画の方法は確実になるのである〔2〕。

\section{2 意識モデルの実例——札幌市における地下鉄乗継システム選択率の予測モデル〔3〕}

まず地下鉄乗継システムに関する札幌市民の意識を知るため，(1) 白石区白石中央，(2) 北区 新琴似，(3) 白石区もみじ台の 3 地区を調査対象地区とし，交通機関の利用意識について調べ た。これらの地区から都心へ行くには，公共大量交通機関として地下鉄・乗継バス，あるいは 直行バスが利用できる。

調査時期は, 東西線延長前の昭和 55 年 9 月である。調査用紙は実験計画法によって設計され た [4]。

（1）乗継システム選択率モデルの構築

交通機関の選択行動を記述する Modal Choice Model の研究は，今日の交通計画に打いて， 総合交通体系の確立といら観点から, 最も重要な課題の一つとなっており, これまでにも数多 くのモデルが提案されてきた。これらのモデルを分類してみると, (1) 行動モデルか, 意識モデ ルか, (2) 集計モデルか, 非集計モデルか, (3) 選択率の推定值が必ず $[0,1]$ の区間に収るか, 否か，によって大別することができる。 
行動モデルは，過去の事実をよく説明できるが，この札幌市の交通体系のように急速に変化 している場合には予測值の外插に疑問がある。また非集計モデルは，計画のための予測モデル としては未熟の感を免れず，推定値が $[0,1]$ の区間に収らないモデルは理論的に疑点がある。 従って,ここでは集計ロジット型の意識モデルを構築することにした。

ところで，この基本型は(1)式のと拈りである。

$$
P=1 /\left(1+e^{G(X)}\right)
$$

ただし， $G(\boldsymbol{X})=\alpha+\beta_{1} x_{1}+\beta_{2} x_{2}+\cdots \cdots+\beta_{n} x_{n}$

ここで，P：乗継システム選択率（\%)

$$
\begin{aligned}
& G(\boldsymbol{X}) \text { : 効用関数 } \\
& \mathrm{e}: \text { 自然対数の底 } \\
& \mathrm{x}_{1}, x_{2}, \cdots, x_{n} \text { : 説明変数 } \\
& \alpha, \beta_{1}, \cdots, \beta_{n} \text { : パラメータ }
\end{aligned}
$$

$G(\boldsymbol{X})$ の説明変数として, $x_{1}$ : 交通目的（通勤・通学 $=1$, 買物・通院 $=0$ ), $x_{2}$ ：乗継ぎ料金 (円), $x_{3}$ ：乗継ぎバス乗車時間(分), $x_{4}$ : 乗継ぎバス運行間隔(分), $x_{5}$ : 直行バス運行間隔(分) の 5 要因を採用し，パラメータ $\alpha, \beta_{1}, \cdots, \beta_{5}$ を表・5 の乗継システム選択率を外的基準として, 非線形回帰法によって算定した。(2) 式はこの算定によって得られたものである。

$$
\begin{aligned}
G(\boldsymbol{X})= & -3.116+0.393 x_{1}+9.60 \times 10^{-3} x_{2} \\
& +3.29 \times 10^{-2} x_{3}+2.68 \times 10^{-2} x_{4} \\
& -2.15 \times 10^{-3} x_{5}
\end{aligned}
$$

ただし，この回帰式 (2)の相関係数は 0.873 である。

（2）意識モデルの予測性の検証

札幌市の地下鉄東西線延長部は，調査より 18 か月後の昭和 57 年 3 月に営業を開始した。こ れによってもみじ台地区から都心へ出るための交通機関選択行動は一変したのである。

それで筆者はその変化をより詳細に分析するため, 昭和 57 年 12 月に交通機関利用実態調査 を実施した。調査対象世帯は，昭和 55 年 9 月の調査と同一であり，462 世帯に配布し，439世 帯から回答を得ることができた。回収率は $95 \%$ である。なお，調査用紙は調査対象世帯に居住 する 18 歳以上の通勤・通学者のみに配布した。回収された個人用紙は 566 サンプルであったが (1 所帯当り 1.3 サンプル), 第 1 , 第 2 回調査の対象者と同一人物と確認できたのはこのらち 316 サンプルであった。それゆえに以後の分析はこの 316 サンプルについて行ならこととする。

図 4 は地下鉄開通前後の交通機関選択率の比較を示したものである。これから次のよらなこ とが分る。

(1) 調査対象者はまじめに回答している。 


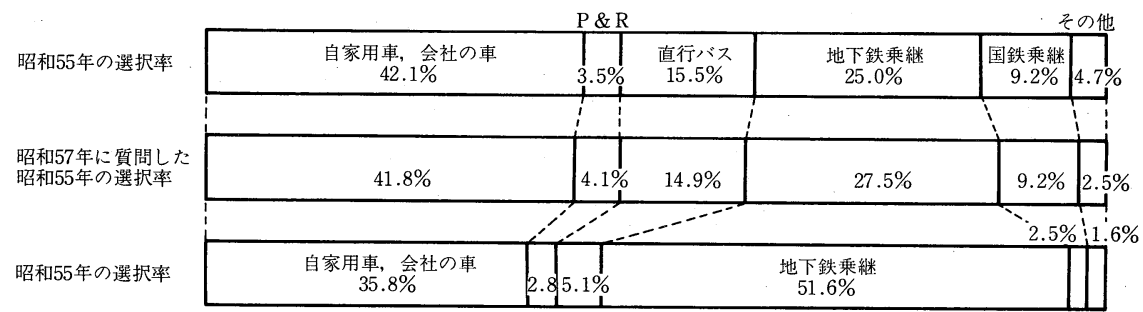

図 4 乗継システム選択率の前後比較

表 1 地下鉄開通による交通条件の変化

\begin{tabular}{|c|c|c|c|}
\hline 要 & 記 号 & $\begin{array}{l}\text { 地下鉄 } \\
\text { 開通 前 }\end{array}$ & $\begin{array}{l}\text { 地 下 鉄 } \\
\text { 開通 後 }\end{array}$ \\
\hline 乗 継 料 金 & $\mathrm{x} 2$ & 170円 & 230円 \\
\hline 乗継バス乗車時間 & $\mathrm{X} 3$ & 30 分 & 10分 \\
\hline 乗継バス運行間隔 & $\mathrm{X}_{4}$ & 10分 & 7 分 \\
\hline 直行バス運行間隔 & $\mathrm{X}_{5}$ & 10 分 & 14分 \\
\hline
\end{tabular}

地下鉄開通の昭和 55 年に調査した選択率と, 開通後の昭和 57 年に, 開通前を思い出して回 答してもらった選択率とが葟とんど一致している。

(2) 地下鉄開通後の交通機関選択は，開通前に比較して大きく変化している。自家用車・会 社の車によるものは約 $14 \%$, パーク・アンド・ライド（P \& R）は $32 \%$, 直行バスは $66 \%$, 国 鉄乗継ぎは $73 \%$ ，その他は $36 \%$ も減少したのに対して, 地下鉄乗継ぎは $88 \%$ も増加している。

このように激しく変化した乗継システム選択率を開通前の昭和 55 年 9 月に調査した意識 データーを用いて構築した集計ロジット形の意識モデルー (2) 式によって予測してみた。

地下鉄が新札幌駅まで延長されたことによるもみじ台地区の交通条件の変化は表 1 のと损り である。

さて，交通目的を通勤・通学としたときの (2) 式は，(3) 式のように書き替えられる。

$$
\begin{aligned}
G(\boldsymbol{X})= & -3.116+0.393 \times(1)+9.60 \times 10^{-3} \times(230) \\
& +3.29 \times 10^{-2} \times(10)+2.68 \times 10^{-2} \times(7)-2.15 \\
& \times 10^{-3} \times(14)=-0.0285
\end{aligned}
$$

ゆえに乗継システム選択率 $P$ は

$$
P=\frac{1}{1+\mathrm{e}^{-0.0285}}=0.507
$$

である。すなわち地下鉄開通前に構築した意識モデル（昭和 55 年 9 月）によって予測した開通 後の地下鉄乗継システム選択率は $50.7 \%$ であり, 開通後の利用実態調査（昭和 57 年 12 月）か ら得られた乗継システム選択率の実績值 $51.6 \%$ とよく一致している。 
表 2 意識モデルの構築例と予測值・実績值の比較

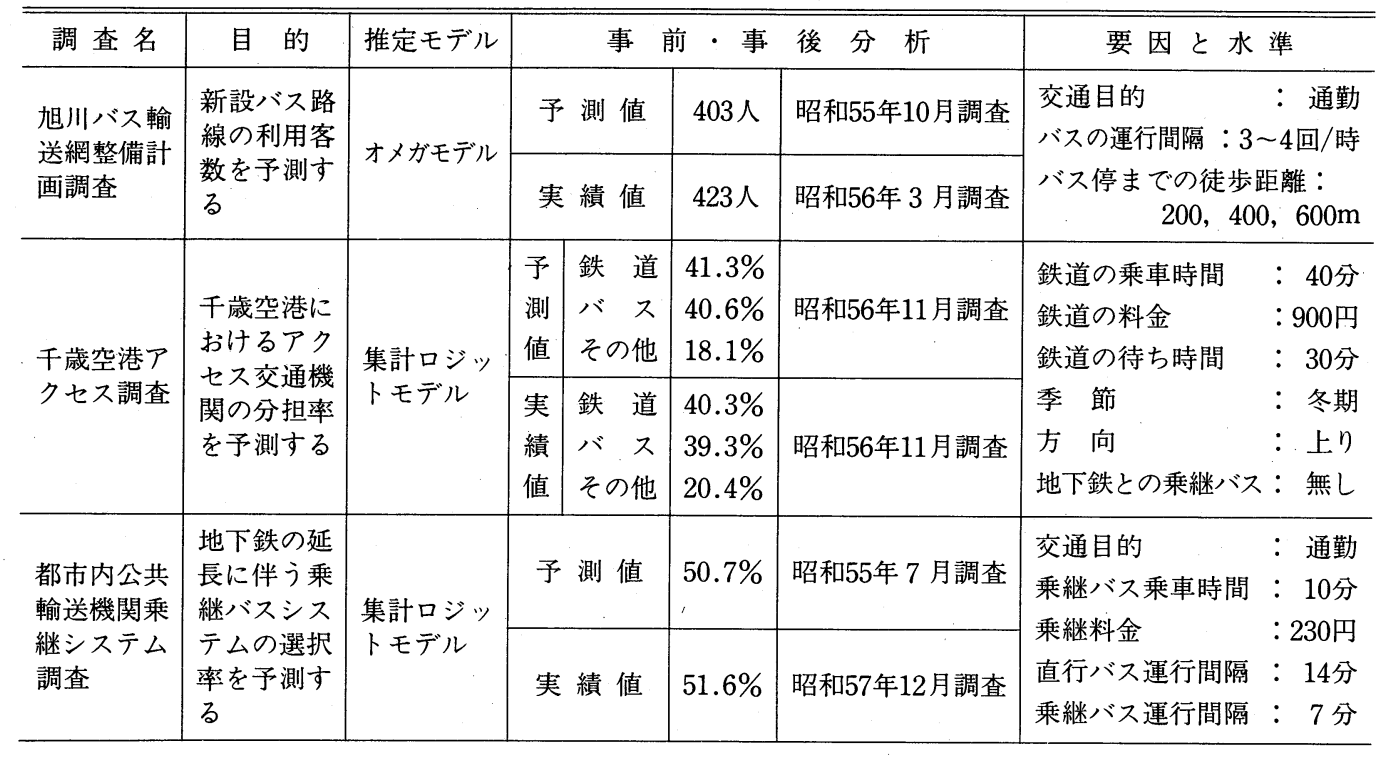

このことは意識データを用いて構築した意識モデルが交通機関の選択行動をよく表わしてお り，交通計画における予測モデルとして十分使用に耐えらることを示している。

なお筆者が構築した既往の意識モデル 3 例における予測值と実績值を比較すれば，表 2 のと おりである。

これらに执いても予測値と実績值がよく一致している。

\section{5. 地域計画における工学的モデル論}

地域計画は科学ではない。技術である。技術は科学を最も重要な基礎としてはいるが，道具 や機械あるいは構造物や施設等を製造，または築設して，現実の生活問題の解決を第一義とし ていることから，科学を超越した手段をもっている。例えば不確実性への対応策としての安全 率の考方などはこれである。

科学においては，不確実性はあくまでも不確実性として論理的合理性という見地からこれを 排除し，事象を解明しょうとする。しかし技術においては不確実性は不確実性としながらも，実 践的合理性という見地からこれを包容し，問題解決を第一義にしょうとする。すなわち，技術 的法令，設計基準，示方書等の規範，あるいは既往の設計図書，処方等の技術的経験，習慣，社 会的許容などに頼って解決を試みる。

ここに筆者が提案した規範論的モデル及び意識モデルが容認される理由がある。この意味に おいて規範論的モデルあるいは意識モデルはすぐれて工学的モデルなのである。そしてこの容 
認は技術者の知性的誠実とそれを認める社会的信頼によって保証される。すなわち, 我々が地 域計画の策定を科学としてょりも技術として位置付けるならば，ここに提案した規範論的モデ ルあるいは意識モデルは地域計画のための有力な工学的モデルとして認められるのである。

最後に実例として挙げたモデルの構築には北海道大学工学部佐藤馨一博士の協力によったので特記して謝意 を表する。

\section{参考 文 献}

[1] 五十嵐日出夫：土木計画における不確実問題, 第 14 回土木計画学シンポジゥム・プロシーディング ス, 土木学会, 1980 年 11 月 15 日, pp. 21 29.

[2]五十嵐日出夫：土木計画に拈ける行動モデルと意識モデル，昭和 58 年度論文報告集, No. 40,土木学 会北海道支部, 1984 年 1 月 31 日, pp. $424 \sim 427$.

[3] 佐藤馨一・五十嵐日出夫：土木施設計画の総合評価手法, 第 1 回土木計画学研究発表会講演集, 土木 学会, 1979 年 1 月 15 日, pp. 171 176.

[4] 佐藤馨一・五十嵐日出夫：実験計画モデルによる交通機関選択行動の事前・事後分析, 土木学会論文 報告集, No. 343,1984 年 3 月 20 日, pp. 151 159.

\section{On the Technological Model of Regional Planning}

by Hideo IGARASHI

(Civil Engineering Department, Hokkaido University)

In the present paper, the scientific models are classified by its characteristics and given the position on the natural and social science axis. (see fig. 2)

Then two new types of the technological model for regional planning are proposed. The one is named the normalogical model and it bears a certain similarity in use to the legal proceedings. The other is named the attitudinal model since it is built with the attitudinal data. An actual example is given to each of the models. 